\title{
Três Imagens do Poder Régio na literatura ibérica do século XIII
}

\author{
José D’Assunção Barros ${ }^{1}$
}

\begin{abstract}
RESUMO
Relacionando sociedade, história e literatura, este artigo busca elaborar uma análise do imaginário do Poder Régio na Idade Média Ibérica, particularmente no século XIII e na Literatura Genealógica deste período. As fontes são as narrativas contidas nos três principais 'livros de linhagens' do Portugal e da Castela medieval.
\end{abstract}

Palavras-chave: Imaginário Régio, Literatura Medieval; Centralização Política.

\begin{abstract}
Associating society, history and literature, this article attempts to elaborate an analysis about the imaginary of the King's Power in the Iberian Middle Ages, particularly in the XIII century and in the Genealogic Literature of this period. The fonts are the narratives of the three principal Genealogic Books of mediaeval Portugal and Castela.
\end{abstract}

Key Words: Kingship’s Imaginary, Mediaeval Literature; Political Centralization.

1 Professor nos cursos de Graduação e Mestrado em História da Universidade Severino Sombra (Vassouras). Doutor em História Social pela Universidade Federal Fluminense. Autor de obras no âmbito da História e das Ciências Sociais, entre as quais contam como publicações mais recentes $O$ Campo da História (Petrópolis: Vozes, 2004) e O Projeto de Pesquisa em História (Petrópolis: Vozes, 2005). 
Existem idéias e imagens que parecem perdurar de maneira particularmente notável ao longo da História - idéias cujo desenvolvimento, desde tempos primordiais, quase soam como um contraponto à própria história das sociedades humanas. Civilizações e culturas, as mais diversificadas, parecem conservá-las no seu elenco de possibilidades práticas ou no seu repertório de representações e de elementos imaginários: as mitologias e religiões as registram; os meios políticos delas se utilizam; mercadores podem comprar e vender produtos com elas relacionados e a vida cotidiana pode revivê-la de diversas maneiras, quando não no concreto vivido, ao menos em um mundo imaginário igualmente carregado de vida e de sentimentos de realidade. Uma destas imagens de força, dificilmente esquecida para onde quer que se volte o olhar para mais um exame da História, é a imagem de 'rei'.

Os reis emergem com facilidade nos vários relatos que nos chegam desde as sociedades mais recentes até as civilizações mais distanciadas no tempo. A Bíblia os menciona bem como mitologias diversas como as da Grécia Antiga e a dos países nórdicos. A política concretamente realizada pelos homens os trouxe à testa dos destinos humanos em inúmeras ocasiões, e ao mesmo tempo as histórias infantis e os contos fantásticos produzidos pelo folclore de diversas sociedades fizeram deles personagens de recorrência quase obrigatória. É sintomático, aliás, que indivíduos que alcançam a proeminência máxima em algum campo das atividades humanas terminem por conquistar na imaginação dos homens o epíteto de 'rei'. E por aí seguem os terrenos onde frutificam as idéias e as imagens associadas à realeza.

$\mathrm{O}$ rei, encarado como figura de força que se incorpora a um governante concreto ou a um soberano imaginário, corresponde em uma primeira instância ao exercício de um poder e de uma liderança centralizada sobre um determinado povo, e não raro se vincula no repertório imaginário deste povo a uma missão que o sacraliza. Antropólogos e historiadores que examinaram várias culturas habituaram-se a se deparar nas suas investigações com uma dupla face que parece acompanhar com notável freqüência a figura régia: a do 'guerreiro' e a do 'sagrado'. Também são encontrados amiúde alguns símbolos recorrentes: a coroa, a espada, o cetro, o palácio ${ }^{2} \ldots$

\footnotetext{
${ }^{2}$ Diversos autores têm estudado a interação entre as faces "guerreira" e "sagrada" que permeia a figura régia. No âmbito da História citaremos a biografia sobre São Luís de autoria de Jacques Le Goff (Le Goff, J. Saint Louis, Paris: Gallimard, 1995). Para já nos situarmos no âmbito da Idade Média ibérica,
} 
No entanto estamos aqui, diante de uma figura que se transforma a despeito de referências comuns que parecem percorrer a idéia de realeza nas várias sociedades a que têm tido acesso os historiadores. Esta 'transformação na permanência' que envolve a idéia de rei, fundada por vezes em novas conexões que emergem ou são produzidas para os mesmos símbolos e imagens de base, não deve nos iludir. É preciso de fato, investigar o imaginário régio naquilo que ele tem de específico com relação a uma dada sociedade. Algumas perguntas se impõem. Como são historicamente reapropriados e reorganizados os símbolos e atributos que compõem habitualmente a imagem da realeza, e que novas conexões entre eles se estabelecem? Que novas funções eles assumem, e como são recebidos pelos vários grupos sociais que para um determinado imaginário social contribuem cada qual com a sua visão de mundo? Que novidades um determinado circuito cultural acrescenta ao repertório de elementos imaginários em que se fundamenta a sua idéia de rei? Que modelos e contramodelos de rei são a partir daí estabelecidos, e de que maneira se relacionam com eles os vários governantes concretos que habitam o mundo político? Como convivem estes diversos pontos de vista e estas várias leituras possíveis que se estabelecem sobre um imaginário régio que se vê partilhado dentro de uma sociedade multidiversificada? Como tudo isto se expressa na literatura e na produção cultural de uma época?

O Imaginário Régio que iremos perscrutar a seguir refere-se a um período e sociedades bastante específicos. Estaremos seguindo o fio da construção da Imagem de Rei nas sociedades do ocidente ibérico do século XIII, e mais particularmente buscando compreender como este imaginário régio se apresenta em uma forma bastante específica de literatura: as narrativas inseridas nos chamados livros de linhagens.

Os livros de linhagens eram genealogias da nobreza ibérica que recobriam tanto as famílias aristocráticas de Portugal como de Castela no período considerado. Postos por escrito entre fins do século XIII e a primeira metade do século XIV, os livros de linhagens mais conhecidos do ocidente ibérico são o Livro Velho, Livro do Deão e Livro de Linhagens, já os enumerando de acordo com as datas de sua compilação ${ }^{3}$. As narrativas

veja-se a obra de José Manuel Nieto Soria (Fundamentos ideológicos del poder real em Castilla. Madrid: Eudema, 1988).

${ }^{3}$ Os livros de linhagens foram compilados em momentos diversos entre o século XIII e XIV, sofrendo sucessivas interpolações até assumirem a sua forma definitiva. São conhecidos basicamente três livros de linhagens: o Livro Velho (LV), o Livro do Deão (LD), e o Livro de Linhagens do Conde D. Pedro, que aqui chamaremos de Livro de Linhagens (LL). Os períodos presumíveis para as suas compilações vão de 1282 a 1290 para o LV, de 1290 a 1343 para o LD, e de 1340 a 1343 para o LL. As três fontes já possuem 
que aparecem nas três genealogias, contudo já circulavam amplamente através da oralidade desde períodos anteriores, conhecendo um ponto alto de difusão com as práticas culturais palacianas e com a atividade dos trovadores ibéricos do século XIII, que além de apresentarem música nos saraus palacianos também costumavam difundir narrativas diversas. São estas narrativas que estaremos aqui entendendo como uma literatura linhagística do século XIII ${ }^{4}$.

Nosso ponto de partida será uma impactante frase sobre a realeza que foi cunhada na mesma época em que circulavam pelos meios nobiliárquicos e palacianos as narrativas linhagísticas da Idade Média Ibérica. "O rei é a cabeça, o coração, e a alma do reino" ... com esta imagem tríplice, expressa em diversos documentos castelhanos do século XIII, os juristas do rei Afonso X de Castela pretenderam registrar da maneira mais completa possível uma nova representação para o modelo de rei preconizado pelo famoso governante hispânico ${ }^{5}$.

O que significa dizer que "o rei é a cabeça do reino"? A imagem da 'cabeça' bem sintonizada com o "simbolismo da ascensão" ou das alturas - implica antes de tudo na idéia de 'topo', de 'ponto mais alto', de 'nível superior' ${ }^{6}$. Dizer que o rei é a "cabeça do reino" é construir uma topografia para o poder, bem fundada no imaginário das alturas. É também pensar a possibilidade de uma separação entre a cabeça e o corpo por

edições diplomáticas importantes. 1 - Livros Velhos de Linhagens. (incluindo o "Livro Velho" e o "Livro do Deão") e 2 - Livro de Linhagens do Conde D. Pedro (ed. José Mattoso e Joseph Piel. "Nova Série" dos Portugaliae Monumenta Historica. Lisboa: Academia de Ciências, 1980).

4 Alguns historiadores têm-se empenhado no estudo dos livros de linhagens como fontes históricas importantes para a compreensão das sociedades medievais ibéricas, entre estes, José Mattoso (A Nobreza Medieval Portuguesa. Lisboa: Estampa, 1987), e Luís Krus (A concepção nobiliárquica do espaço ibérico. Lisboa: Calouste Gulbenkian, 1994).

5 José Maravall ressaltou por trás desta tríplice metáfora a especificidade daquilo a que chamou de um "caráter corporativo" do reino castelhano-leonês em oposição ao regime feudal propriamente dito (Maravall, J. A. "Del régimen feudal al régimen corporativo en el pensamiento de Alfonso X": Estudios de Historia del pensamiento español. I. Madrid: 1973, p.133-135). Neste artigo estaremos examinando de outra perspectiva esta tríplice imagem régia: a de que ela permite precisamente a complementaridade de três posições políticas distintas.

${ }^{6}$ Algumas constelações de imagens, conforme estudos de autores diversos costumam aparecer agrupada no âmbito daquilo que Gilbert Durand chamou "regimes imaginários" (Durand, G. As Estruturas Antropológicas do Imaginário. Lisboa: Presença, 1989). Ao percorrer esta perspectiva, Durand situa-se dentro de uma rede de autores que inventariaram e classificaram com bastante eficácia repertórios de símbolos imaginários em alguns casos com resultados similares. Para o circuito de civilizações indoeuropéias, registraremos Georges Dumézil (Essai de philologie comparative indo-européenne. Les Mythes romains, III. Paris: Gallimard, 1947) e A. Piganiol (Essai sur les origines de Rome. Paris: Boccard, 1917. p.140). R. Desoille elaborou um inventário similar, mas já operando dentro do campo da psicanálise (L'Exploration de l'activité subconsciente par la méthode du rêve éveillé. Paris: D'Artrey, 1938). No campo da psicanálise literária destacam-se Baudouin (Psychanalyse de Victor Hugo. Genève: Mt-Blanc, 1944) e Pierre Guiraud (Index du vocabulaire du symbolisme. Paris: Klincksieck, 1953). 
ela governado, ou entre o rei e o seu povo. Construir um 'topo político', enfim implica em gestos e estratégias bem diferenciados daqueles que são requeridos para a construção de um 'centro político'.

É assim que, ao se elaborar a idéia de que "o rei é a cabeça do reino", investe-se a figura régia de determinadas virtudes - da 'altivez' geradora de soberania à 'coragem' modeladora do heroísmo. Investe-se também em determinada imagem da hierarquia social - aqui vista como o espectro ou escada que vai encontrar na figura régia o seu degrau mais alto para além do qual só existe mesmo o mundo divino.

Mas há algo que se perde neste circuito simbólico que lança o rei para as alturas ou para o imaginário celeste do seu povo. Este distanciamento, que por um lado o aproxima de Deus, também afasta o governante dos demais homens - e nem sempre esta é a situação mais desejável. Por isto, outros imaginários do poder fundam-se na construção da noção de um 'centro político'. Este já pressupõe um investimento simbólico na idéia de intimidade de que o governante ou o núcleo político é uno com o seu povo, de que um está entranhado no outro, de que o governante é o próprio povo, ou pelo menos o povo condensado em todos os seus melhores aspectos.

A imagem que a literatura ibérica do século XIII encontrou para expressar este outro circuito de idéias e de sentimentos é a de que "o rei é o coração do reino". Eleger este novo órgão como o símbolo do poder é abrir mão do universo das alturas em favor do universo mais íntimo do pulso, do ritmo da terra, da vida que é regida a partir de um núcleo, do controle que se dá a partir de dentro e não mais de cima. Implica também em deslizar dos valores da coragem desmedida e da justiça implacável e discriminatória para a província da 'temperança', que eqüidistante dos extremos lida com os contrários, realizando um outro gesto do governar.

Mas existe por fim, a idéia de que o rei não governa nem de cima e nem de dentro, mas de fora de algum ponto que transcende o organismo social e que, estando em todos os lugares, não está concretamente em lugar nenhum. Esta última idéia foi condensada pelos medievais-ibéricos na imagem de que "o rei é a alma do reino". O rei não seria neste caso nem o ponto mais alto nem o ponto mais central do reino, mas algo que está fora dele, embora o anime - do mesmo modo que a alma comanda o corpo, embora não seja este mesmo corpo. Parceiro de Deus e portador de missão sagrada, este monarca transcende o reino ao invés de a ele se superpor ou de incorporá-lo. Aos mundos do 'ar' e da 'terra', a alma vem trazer o elemento 'fogo' (o mais incorpóreo dos elementos). 
Aos homens de Portugal e da Castela medieval foi preciso investir significativamente no direito humano às ambigüidades - direito que por vezes se perde no mundo do racionalismo moderno - para encampar simultaneamente as três imagens acima descritas na célebre frase, proferida no século XIII, de que "o rei é a cabeça, o coração e a alma do reino". Quem olhasse ou refletisse sobre esta frase, inscrita que fosse a um código jurídico ou nos cantares de um trovador, estaria simultaneamente contemplando a idéia de que o rei está acima, dentro e fora do reino, governando-o simultaneamente a partir destes três lugares aparentemente contraditórios, mas que se irmanam momentaneamente na figura régia.

Dentro dos limites deste texto iremos apenas exemplificar alguns casos que ilustram a presença - nas narrativas linhagísticas do século XIII - das imagens do rei como "cabeça", "coração", ou "alma", neste último caso, transcendendo em alguns momentos o âmbito meramente corporativo e permitindo que o rei aja de forma mais independente. Neste particular, cumpre desde já considerar que as duas primeiras imagens - "cabeça" e "coração" - opõem-se à imagem da "alma" precisamente por serem imagens corporativas, enquanto que a última é a própria imagem da transcendência do rei que está em toda parte, mas em nenhum lugar, e que embora controlando o corpo político possa agir com independência em relação a ele ${ }^{7}$.

Os livros de linhagens trazem diversas narrativas onde o rei parece desempenhar o papel de "cabeça" do corpo social, esteja este corpo social referido ao reino como um todo ou a um segmento nobiliárquico, diante do qual, o rei apresentar-se-á como um ponto mais alto. O rei será visto então como alguém que governa de cima. Porém, como os livros de linhagens são fontes tipicamente nobiliárquicas, geralmente estas narrativas enfatizam a idéia de que esta cabeça depende do corpo, de que ela não tem uma existência por si só. Por vezes, ainda, as narrativas linhagísticas deixam passar a idéia de que, para além da figura régia, a verdadeira cabeça do reino é constituída por um conjunto de nobres que aconselham o rei. Neste caso mais específico, o rei mostra-se aqui apenas como a parte mais visível de uma cabeça compósita.

As narrativas em que isto ocorre mais visivelmente são aquelas que relatam casos de 'imposição da justiça', de 'guerras' onde o concurso da nobreza é imprescindível para a vitória ou então as narrativas que se referem ao modo de governar - seja para

\footnotetext{
${ }^{7}$ Sobre o estudo das imagens corporativas integradas ao imaginário régio, veja-se a célebre obra de Ernst Kantorowicz, Os Dois Corpos do Rei (São Paulo: CIA das Letras, 1998).
} 
enaltecer um governo bom e justo ou para condenar um governo ruim e injusto. Ao mesmo tempo também aparecem aqui os casos de processos régios comandados pelo rei. Um rapto, um crime cometido, uma injustiça perpetrada, uma rixa interminável entre duas famílias nobres - tudo pode gerar a necessidade de uma mediação de conflitos comandada pelo rei ou então a necessidade de que a justiça seja restabelecida através da violência centralizada (ou encimada) pelo rei.

Mas há certas nuanças que devem ser aqui observadas, em vista do fato de que estamos falando de fontes nobiliárquicas em um período histórico em que certos setores da nobreza lutavam por demarcar seu espaço social diante de um processo centralizador conduzido pela realeza. Tanto em Portugal com D.Afonso III e depois D.Dinis, como em Castela com Dom Afonso X tinha um processo de centralização que gradualmente se intensificava, gerando as inevitáveis resistências. É diante deste contexto que as narrativas nobiliárquicas do período descrevem um modelo de mediação ou ação régia, onde o rei é sempre impulsionado e assessorado por um corpo de nobres que o aconselham. A "boa realeza" faz-se acompanha da "boa nobreza".

Quando o rei é mal aconselhado, ele se torna uma má cabeça para o reino - e muitas vezes, acaba perdendo a sua própria. Vale exemplificar com um dos mais notáveis exemplos incluídos nos livros de linhagens acerca da aludida situação de complementaridade entre a 'boa ou má nobreza' e a 'boa ou má realeza'. Trata-se da narrativa sobre "O rei Pedro de Castela" incluída do Livro de Linhagens de Conde D. Pedro (LL 21A15) ${ }^{8}$. O problema é colocado logo de princípio do texto: da situação ideal do rei que é 'bem aconselhado' por bons nobres de alto valor moral e de boa linhagem e que por isto governa a contento - o personagem central resvala em seguida para a situação do rei que é secundado por privados da pior qualidade ${ }^{9}$. Acresce o detalhe de que após a partida de um privado nobre que cumpria um bom papel de aconselhamento, o rei de Castela preferiu cercar-se de privados, que não apenas, eram de baixa índole moral como também eram não-aristocratas - aspecto que terá alguma relevância na

\footnotetext{
${ }^{8}$ Neste artigo utilizaremos as abreviaturas LL, LV e LD para nos referirmos as narrativas respectivamente contidas em cada um dos três livros de linhagens: o Livro de Linhagens do Conde Dom Pedro, o Livro Velho de Linhagens e o Livro do Deão. A narrativa em questão (LL 21A15) provém de uma das refundições do Livro de Linhagens (a de 1265 ou a de 1283), uma vez que se refere a um personagem contemporânea a Afonso IV de Portugal. Em todo o caso, incorpora perfeitamente o espírito nobiliárquico das narrativas oriundas de períodos anteriores.

${ }^{9}$ Outra narrativa do Livro de Linhagens do Conde Dom Pedro poderia ser dada como exemplo desta passagem da "boa realeza" assessorada por "bons nobres" à "má realeza" assessorada por "maus nobres": a Narrativa sobre o reinado de Sancho II (LL7C-7)
} 
narrativa, já que euforiza a importância de que um monarca se cerque de bons conselheiros pertencentes à nobreza. Nada mais claro:

"E depois que se del partio dom Joham Afonso d'Alboquerque e de Medelim, que o conselhava mui bem e verdadeiramente com gram prol dos fidalgos e dos outros do reino, houve privados que o conselharaom mui mal, prazenceando e dando-lhes mal conselhos por tirarem del mercees, e fezerom-no viver com grandes pecados, filhando muitas molheres, que lhe foi maa estança, e matou muitos e boos d'alto linhagem [...]"10

Depois de uma série de desvios e crueldades secundadas pelos maus conselheiros, o rei é deposto uma primeira vez e, reincidente, termina exemplarmente decapitado por um nobre honrado (o conde Henrique de Castela). A narrativa encerra-se de maneira didática, quase a maneira de um pequeno 'espelho de príncipes':

"Este rei leixou exemplo pera os reis haverem boos conselheiros, leaes e entendudos e leterados, de boa conciencia e sem prazenteo. E antre estes, dous homees boos e de boo sangue e ricos e de grande estado, que lhe digam as cousas sem receo. E por esto o passou mal este rei dom Pedro, que se meteo em poder d'homees viis, assi como netos de celorgiães e barqueiros que soiam a seer. E o rei a que Deus dá entendimento, se creer os boos conselheiros, ama-lo-á Deus, e os boos do reino e todasas outras gentes, assi que sempre vivirá em prazer, e quando morrer irá aa gloria celestrial"

Chama atenção o interdito preconizado nesta e em outras narrativas pelos autores do nobiliário: não apenas o rei deve escolher bons conselheiros como deve selecioná-los preferencialmente (ou até obrigatoriamente) na boa nobreza do reino. Portanto, a situação ideal preconizada pelo nobiliário encontra-se na sintonia eficaz do 'bom rei' com os 'bons nobres'. A complementaridade entre a 'boa nobreza' e a 'boa realeza' enquanto personagens do discurso linhagístico e até a intervenção marcante da primeira na constituição da segunda (o 'bom nobre' construindo o 'bom rei' como um educador implícito ou como o personagem que pressiona e exige do personagem régio o correto cumprimento do seu papel) - eis aqui um traço do discurso linhagístico onde se desenvolve a imagem do rei como "cabeça" do reino.

No âmbito das narrativas de "mediação régia" também aparecem amiúde, os relatos de processos judiciais ou de restauração da justiça que, embora mediados pelo

\footnotetext{
${ }^{10}$ Livro de Linhagens do Conde D. Pedro. LL 21A15 (este e o trecho seguinte). Além desta narrativa contra-paradigmática sobre "D. Pedro de Castela", diversos outros exemplos de reis transgressores que são depostos podem ser encontrados em narrativas incluídas nos livros de linhagens - como naquelas referentes aos circuitos troiano e bretão: "Rei Argal" (LL 2C26); "Rei Cotianus" (LL 2C32); "Rei Grantiam" (LL 2D8); "Membriz" (LL 2B8); "Marpidus" (LL 2C25).
} 
rei, são conduzidos em algum nível mais importante pelos próprios nobres mais próximos ao monarca, seja porque estes o pressionam ou porque o aconselham relativamente à decisão correta a ser tomada ${ }^{11}$.

Desta maneira, as várias narrativas de mediação régia que podem ser examinadas no material linhagístico revelam sistematicamente o fundamento da intervenção nobiliárquica por trás da intervenção régia de superfície. Ao menos em alguns estratos de sentido, o nobre é o verdadeiro 'sujeito' por trás do 'sujeito'.

De resto, seria dizer que a leitura nobiliárquico-linhagística da mediação régia revela a idéia de uma 'mediação compósita'. A entender por aqui, o processo de mediação régia não diz apenas respeito ao rei, mas ainda com mais propriedade à nobreza ou a uma parcela da nobreza - que se vê representada no corpo de nobres que aconselham ou pressionam o governante mediador. O 'rei', como cabeça de um corpo político, poderíamos acrescentar, não se reduz nesta leitura à figura individualizada de um monarca singular, mas engloba uma "autoridade compósita" que se constitui da dualidade integralizada pelo rei propriamente dito e pelo seu corpo de 'bons nobres' aconselhadores. Com isto, a imagem da 'cabeça' - reduto simbólico da realeza - parece ser invadida por um setor da nobreza que lhe disputa a autoridade efetiva, o que testemunha um pouco desta complexa guerra de representações que se estabelece no interior da idéia da 'mediação régia'.

A segunda imagem do rei a ser compreendida é a do "coração". Se a 'cabeça' situa-se altivamente acima do corpo, seja examinada como parte dele integrante ou em separado, já o ‘coração' é por outro lado aquele órgão que está intimamente entranhado no corpo - nele ocultado e com ele confundindo-se. Sem mostrar-se visível como a 'cabeça', mas pulsando ininterruptamente para mostrar a sua imprescindível presença; o 'coração' rege o corpo de dentro e integraliza o intercâmbio com os demais órgãos - de modo que é por ele que o essencial do processo vital circula. Por isto, o 'coração' tornase o símbolo ideal para expressar a "junção de todos" e a própria vida. É também de longa data, já no período medieval, a utilização do 'coração' como o mais eficaz símbolo do amor e da união. À altivez da cabeça, parte do corpo que se quer mostrar a todos e que individualiza, opõe-se a humildade do coração, órgão que se quer oculto.

\footnotetext{
${ }^{11}$ Uma narrativa típica deste caso é a LL 36BN9, incluída no Livro de Linhagens do Conde Dom Pedro. 
Daí que a imagem da 'cabeça' apareça na metáfora dos juristas medieval-ibéricos, tão bem contrabalançada e neutralizada pela imagem do 'coração'. A passagem bilateral e ambivalente de uma imagem a outra, complementa de certo modo um programa de governo. Ela mostra como os pensadores políticos da Idade Média Ibérica já se preocupavam com o balanceamento entre 'separação' e 'fusão' dos governantes com os seus governados. Passaremos a examinar neste momento como o rei - que vimos apresentar-se em um primeiro momento como 'cabeça' - deve tornar-se agora o ‘coração' para completar o segundo terço da metáfora tão bem expressa pelos sábios ibéricos.

Através da imagem do coração, do órgão que se constitui em 'centro' e não em 'topo', será possível examinar em seguida os elementos, mediante os quais o rei 'integra-se' (ou é integrado) à sociedade que pretende governar. Integrar-se a uma sociedade tão rigidamente hierarquizada como a que anima cada um dos dois principais reinos da sociedade ocidental-ibérica medieval é integrar-se não apenas ao todo, mas também a cada uma de suas partes. O rei vale dizer, deve buscar mecanismos de coesão e de identificação com os grandes grupos sociais nos quais se reparte a sua sociedade.

É possível examinar nas fontes nobiliárquicas e régias do século XIII, dois momentos que compõem este esforço de integração. Por um lado temos os mecanismos culturais consoante os quais o rei integra-se especificamente à nobreza, enquanto um primus inter pares. Por outro lado temos também os mecanismos culturais mediante os quais, o rei integra-se ao 'reino' como um todo - o que inclui, além da nobreza, os grupos sociais laicos não-aristocráticos para não falar da população clerical.

Como estamos tratando aqui destas fontes essencialmente nobiliárquicas que são os livros de linhagens sintetizaremos particularmente os aspectos relacionados ao primeiro momento. De fato, o primeiro esforço de integração do rei - ou o seu primeiro compromisso - é o de ser um nobre (o primeiro dos nobres). Isto se dá por uma via dupla: de um lado o rei mostra-se um modelo para a nobreza; de outro pretende assimilar os modelos da nobreza (isto é, a nobreza e seus valores cavaleirescos como um modelo para o rei). Do ponto de vista da nobreza ocorre o mesmo e particularmente a imagem do rei será construída na literatura nobiliárquica mediante o mesmo duplo processo. Nesta literatura, assim realeza e nobreza estabelecem uma relação bivalente, onde o rei e o mundo cavaleiresco da nobreza tornam-se modelos recíprocos. 
Um rastreamento intensivo das narrativas incluídas nos livros de linhagens mostra que as duas preocupações fundamentais desta literatura são precisamente o "ideário cavaleiresco" e a "solidariedade nobiliárquica"12. De um lado é preciso mostrar que o rei está perfeitamente integrado ao ideário cavaleiresco que se produz no seio da nobreza de seu reino, por outro lado é preciso mostrar que o rei está inarredavelmente preso a uma rede de solidariedades nobiliárquicas como qualquer outro nobre. A maior parte das narrativas dos livros de linhagens que envolvem de alguma maneira a figura régia, seja como ator principal ou como figura coadjuvante, constrói-se precisamente em torno de uma destas questões ou das duas juntas perfeitamente imbricadas.

Com relação ao primeiro problema, há basicamente duas formas de integrar o rei à nobreza através do ideário cavaleiresco. A mais óbvia é absorvendo-o diretamente aos seus valores. A mais sutil é aprisionando-o nos seus problemas. Mostrar um rei que participa do drama cavaleiresco no que ele tem de mais humano - não apenas no que ele tem de mais heróico como também no que ele tem de fragilidades e contradições a superar, eis aqui um projeto que se viabiliza nos livros de linhagens.

Os nobiliários contribuem com várias de suas narrativas para sedimentar esta idéia de que acima do poder régio existe um ideário cavaleiresco do qual o próprio rei não pode fugir. Assim, se interessa ao governante régio apropriar-se deste ideário no seu esforço de integração ao reino também interessa à nobreza construir a imagem de um rei que deve agir conforme estes parâmetros oriundos da cultura nobiliárquica - e reside aí uma dupla motivação para a ampla ocorrência nesta literatura de um ideário cavaleiresco que se sobrepõe ao próprio imaginário régio. $\mathrm{O}$ rei revela-se, ainda aqui, mais um nobre entre os nobres - mesmo que na situação ideal ele seja o mais valoroso dos nobres.

Entre numerosos exemplos existe uma narrativa do Livro de Linhagens do Conde Dom Pedro em que um nobre casado com a filha do próprio imperador acaba assassinando-a equivocadamente ao imaginar erroneamente que estaria sendo vítima de adultério (LL11C7). Percebendo o erro, o nobre se entrega espontaneamente para o imperador julgamento e neste é exposto o caráter fatídico e involuntário do crime e o fato de que, a considerar as prescrições do código cavaleiresco para as questões de honra, o nobre agira perfeitamente de acordo com o ideário cavaleiresco. Obrigando-se

\footnotetext{
${ }^{12}$ Este rastreamento foi empreendido em nossa pesquisa anterior (BARROS, José D’Assunção. As Três Imagens do Rei - o Imaginário Régio nos livros de linhagens e nas cantigas trovadorescas portuguesas (séculos XIII e XIV), Niterói: UFF, 1999, tese de doutorado. Capítulo IV.1.
}

Mediações - Revista de Ciências Sociais, Londrina, v. 10, n.1, p. 41-58, jan.-jun. 2005 ISSN 1414-0543 TRÊS IMAGENS DO PODER RÉGIO NA LITERATURA IBÉRICA DO SÉCULO XIII José D'Assunção Barros 
a esquecer por um instante em magnífico esforço de imparcialidade, que ele é também o pai da vítima, o imperador-juiz termina por absolver o nobre. Demonstra-se, a partir deste fecho narrativo, que mais uma vez o 'rei-mediador' é instrumento de uma força maior - e que algo julga acima dele: o próprio 'código cavaleiresco'. Ou ainda, visto por um outro ângulo, que o rei não está acima, mas no centro de um corpo nobiliárquico ao qual deve permanecer integrado.

Com relação ao aspecto da "solidariedade nobiliárquica", segundo fator evocado nas narrativas linhagísticas para explicitar a integração do rei à nobreza - e, portanto reforçar a sua imagem como "centro" e não mais como "topo" - é digno de nota que os próprios mecanismos que regem a 'solidariedade nobiliárquica' e que aprisionam também o rei acham-se registrados no próprio Prólogo do Livro de Linhagens do Conde Dom Pedro, o mais completo dos três nobiliários da época. Este Prólogo não perde a oportunidade de assinalar em vários momentos, a unidade matricial entre nobreza e realeza - mostrando que casas reais e casas nobres remetem-se mutuamente, já que descendem umas das outras (idéia que é concretamente apresentada em diversas oportunidades do livro com a própria enumeração nobiliárquica). Esta unidade matricial, coerentemente, remete a uma solidariedade natural entre o rei e os nobres (LL, "Prólogo", 13), e na verdade atua em consonância com a imagem régia do "coração".

Pode ser mencionado ainda um último circuito de exemplos sintonizado com a imagem do coração. Talvez um dos mais belos esforços de integração social da imagem do rei através da cultura - não mais apenas ao corpo nobiliárquico, mas agora ao reino na sua totalidade - seja a edificação de sua corte trovadoresca. Não apenas a sociedade inteira aí se vê representada em uma polifonia de tipos e categorias sociais, que não raro se resolve sob a mediação régia, como o próprio rei pode converter-se ele mesmo em objeto da trova e mesmo de sátira - isto sem contar a possibilidade de o rei tornar-se um trovador, como todos os outros, sujeito às mesmas regras do organismo trovadoresco dentro do qual ele ocupa a função de um "centro", mas nunca de um "topo". Tal foi o caso, por exemplo, de Afonso X em Castela e de D.Dinis em Portugal, reis-trovadores da segunda metade do século XIII que centralizaram em torno de si, dois dos mais efervescentes ambientes trovadorescos de sua época.

Passaremos agora à imagem que completa a tríade imaginária que estamos discutindo. Até aqui vimos como a imagem do rei, seja nas narrativas linhagísticas ou no espaço trovadoresco, era freqüentemente construída em torno de uma ou outra de 
duas idéias corporativas distintas. Ou o rei imaginário integra-se ao corpo social com ele se confundindo ou o rei é erigido em órgão privilegiado que governa acima deste corpo social. As duas imagens, embora radicalmente distintas, são pensadas ao nível do corpo, evocando respectivamente as simbologias organizadas pelas metáforas do 'coração' e da 'cabeça'.

Destarte, existe uma terceira maneira de se pensar o rei - como figura que transcende o universo corporativo. Os juristas de Afonso $\mathrm{X}$ de Castela completaram a metáfora régia com o símbolo da 'alma'. Muito se poderia discorrer em relação a este terceiro mundo de atributos imaginários que evoca fundamentalmente o aspecto da 'sacralidade'. O rei, na Idade Média como também em outros tempos, é freqüentemente associado a uma missão que lhe é confiada por um mundo transcendente, divino ou sobrenatural. Pode ser ungido como os reis bíblicos do Antigo Testamento ou ser sancionado por um universo mágico como no caso do rei Artur pode receber um dom especial e transcendente como os reis taumaturgos estudados por Marc Bloch, tornar-se santo ou revelar-se o maior dos pecadores e ainda assim se mostrar protegido pelos deuses ou pelo mundo sobrenatural pelo simples fato de que no exercício de sua missão o rei equivale à 'alma do reino'.

Antes de qualquer coisa convém notar que as narrativas dos livros de linhagens constituindo-se estes essencialmente em documentos corporativos da nobreza favorecem com alguma espontaneidade as imagens do corpo. Procura-se assimilar o rei ao corpo nobiliárquico, predominando talvez os fatores de integração sobre os fatores de separação - e de uma maneira ou de outra se pode notar que o rei dificilmente atua sozinho. Entranhado no corpo como um 'coração' ou superposto a ele como uma 'cabeça' que regula o movimento ou as relações entre os demais membros e órgãos, o rei age quase sempre como parte constituinte de um corpo. Pouco lugar há nos nobiliários para a ação individual ou isolada de um rei, já que os nobiliários se destinam a exaltar precisamente um corpo - o corpo nobiliárquico. Mais fácil do que uma narrativa linhagística exaltar a ação individual de um rei é ela exaltar o heroísmo individualizado de um nobre e assim mesmo, quando este nobre torna-se o arquétipo de um heroísmo coletivo, que pertence na verdade a este grupo social que é a nobreza. $\mathrm{O}$ herói nobre, em todos os casos, é porta voz da nobreza.

Por outro lado, a tendência dos livros de linhagens é a de depreciar os reis transcendentes, tanto os que agem individualmente menosprezando o concurso do 
auxílio nobiliárquico (ou do corpo social como um todo) como aqueles que extrapolam as funções régias e o plano de atuação cristã-cavaleiresca. As narrativas do ciclo bretão e troiano (títulos $2 \mathrm{~B}$ e $2 \mathrm{C}$ ), por exemplo, parecem desempenhar no nobiliário do Conde D. Pedro uma função didática com relação a estas questões bem ilustradas com variados exemplos. O rei Cotianus (LL 2C32), que "foi homem de maa vida, que nunca soube guardar amigo", enfrenta um levantamento e é punido por não cultivar o padrão de solidariedade nobiliárquica que já vimos constituir um dos eixos básicos do discurso linhagístico. O rei Grantiam (LL 2D8), que "viltava os homees boos da terra", é assassinado por um levante similar. Já o rei Membriz, "que feria e viltava toda sa campanha" (LL 2B8) e o rei Morpidus, que não respeitava o estatuto dos seus nobres (LL 2C25), são justiçados pela própria natureza, respectivamente por uma matilha de lobos e por um monstro marítimo ${ }^{13}$. Ao lado destes reis individualistas ou transgressores aparece o relato sobre o "Rei Balduc", que transcende o seu ofício régio e explora um saber mágico que culmina em "fazer aas por voar" até que, punido pela ordem natural que transgredira, "faleceo seu sem e caio em terra e quebrou todo, e assi morreo" (LL 2C9). Todos estes monarcas, embora plenamente imbuídos de valores guerreiros, fracassam precisamente por terem transcendido o corpo social de maneira individualista ou por terem transcendido o bom ordenamento social e natural do mundo.

Posto isto, pelo menos uma aventura registrada nos livros de linhagens, e na verdade um dos mais famosos e mais longos de seus relatos extrapola a habitual moldagem de uma imagem régia vinculada exclusivamente ao código cavaleiresco e à ação perfeitamente inserida no corpo nobiliárquico. Referimo-nos aos relatos sobre "O Rei Ramiro em Gaia”, que se cristalizaram em duas versões narrativas que aparecem no Livro de Linhagens do Conde Dom Pedro e no Livro Velho de Linhagens.

Possivelmente era uma das narrativas que mais circulavam no circuito de oralidade das narrativas linhagísticas. Disto dá mostras à múltipla reapropriação deste relato, que nos legou uma primeira versão escrita no final do século XIII ${ }^{14}$, bem como outra cristalizada em um primeiro momento pelos genealogistas do século XIV e mais adiante pelo refundidor do final deste mesmo século. Atribui-se a este último

\footnotetext{
${ }^{13}$ KRUS, Luis. A concepção nobiliárquica do espaço ibérico. Lisboa: Calouste Gulbenkian, 1994. p.152.

${ }^{14}$ Ao Livro Velho, Artur Botelho da Veiga atribui a data de 1272 (Os Nossos Nobiliários Medievais. Alguns elementos para a cronologia da sua elaboração. Anais das Bibliotecas e Arquivos, 15 . 1940, publ. 1942, p.165-193). José Mattoso propõe a correção desta data para um intervalo situado entre $1282 \mathrm{e}$ 1290 ("Introdução" In: Os Livros Velhos de Linhagem. p.13).
} 
compilador, responsável por alguns acrescentamentos ao título XXI do Livro de Linhagens do Conde D. Pedro, um colorido literário que também aparece em algumas outras narrativas.

Quanto ao conteúdo básico, o lendário relato sobre o "Rei Ramiro em Gaia" envolve na sua primeira parte dois raptos entrecruzados. Apaixonado por uma princesa moura ou pelas "maravilhas" que dela ouvira dizer, um rei cristão resolve raptá-la. Em contrapartida, o rei mouro que era seu irmão vinga-se raptando a esposa do rei cristão. A segunda parte do relato aborda as aventuras do rei cristão no território inimigo, utilizando-se de todos os estratagemas possíveis para reaver a mulher - para depois compreender que a rainha já preferia àquela altura o mouro que a raptara. Depois de punir exemplarmente a antiga rainha, o rei cristão retorna ao seu reino e casa-se com a princesa moura, batizando-a e fazendo dela uma rainha da cristandade.

Alguns aspectos chamam bastante atenção neste relato, e convém examiná-los mais de perto. Para começar, este Rei Ramiro, um rei cristão que é apontado nos nobiliários como um baluarte dos primeiros tempos da Reconquista, age frequientemente de modo não cavaleiresco, indo mesmo contra alguns preceitos fundamentais da moral cristã. Apaixonado por uma princesa moura da qual apenas ouvira falar, propõe de saída a um inimigo mouro casar-se com esta princesa que é sua irmã, já tendo ele mesmo uma esposa e filhos. Para tal, chega a defender a idéia de que seu casamento anterior poderia ser anulado pela Igreja, já que ele e sua esposa eram parentalmente próximos.

Como não é aceito em suas pretensões pelo rei mouro - um chefe islâmico que parece estar mais afinado com o código cavaleiresco do que ele - resolve por fim raptar a dama que lhe fora negada. A partir daqui, não faltarão episódios onde este rei agirá individualisticamente, transgredindo o código cavalheiresco e a moral cristã, agindo mais com uma bem calculada astúcia do que com uma heróica ferocidade, mentindo acintosamente em diversas ocasiões e colocando por vezes objetivos egoístas acima dos objetivos do reino.

A narrativa incorpora de pronto uma tensão que irá constituir a figura deste monarca emblemático: o confronto entre a sua missão sagrada e o seu perfil demasiado humano. A missão de retomar a terra aos mouros e reconstruir a unidade cristã na Espanha é incorporada ao protagonista mediante a sua inserção genealógica na rede de monarcas reconquistadores, e existe ainda uma outra narrativa que nos fala de ele ter recebido esta missão diretamente de um anjo em uma tenda de campanha. Mas ao 
mesmo tempo em que é desenhada a dimensão sagrada da missão deste rei, introduz-se desde já o seu perfil humano e a sua dimensão individual.

As contradições entre as duas naturezas se sucedem. Motivado por uma paixão pessoal, o rei se vale de artes mágicas para raptar a princesa moura. Deste modo, este rei não parece resolver os seus problemas exclusivamente no âmbito cristão ou tampouco no âmbito cavaleiresco, tal como se verá no decurso do relato. Da mesma forma, sua atuação traz uma forte carga de individualidade. E, ainda assim, este rei cristão das Astúrias vê-se inserido em uma missão mais ampla que ao final de tudo acaba por se sobrepor aos seus projetos pessoais.

Uma vez realizado o rapto, torna-se explícito o confronto entre os mouros de Alboazer - o monarca islâmico - e os cristãos liderados pelo Rei Ramiro. O caminho de que se serve o rei mouro para reparar o mal que o rei Ramiro lhe impusera é o de raptar a esposa do rei cristão. Com este segundo rapto que é contraposto ao primeiro, a situação se equilibra. A primeira parte da narrativa se encerra e arma-se o cenário para uma aventura quase individual do monarca cristão.

A segunda parte da lenda de Gaia aborda um novo percurso do rei Ramiro no mundo islâmico, agora com o intuito de resgatar a esposa raptada. Ciente do rapto que ora lhe fora infligido, o rei cristão prepara com alguns nobres escolhidos uma verdadeira empreitada para recuperar a sua primeira esposa, mas na qual ficará patente mais do que tudo, uma atuação marcadamente individualizada do rei.

É assim que o rei esboça um plano no qual um barco camuflado em panos verdes de modo a ser confundido com vegetação, ocultará todos os seus guerreiros nobres, que acederão ao seu chamado para a luta após escutarem o som prolongado de uma corneta soprada pelo rei. O rei em contrapartida penetra sozinho na cidade inimiga e no castelo vestido de mendigo de modo que a partir daqui entramos no plano da atuação perfeitamente individualizada do heroísmo régio. É só de suas próprias qualidades pessoais que dependerá o monarca - de sua sabedoria e astúcia, de seu poder de disfarce e manipulação, de sua persistência e presença de espírito, e mesmo de sua capacidade de infringir pequenos valores cavaleirescos com vistas a um fim maior, mentindo e enganando, por exemplo.

A aventura individual do rei Ramiro começa com um disfarce de mendigo através do qual logra penetrar no palácio inimigo. $\mathrm{O}$ 'disfarce' é desta maneira, o primeiro estratagema astucioso do rei. Observe-se que até aqui, o monarca imagina que terá 
como uma aliada em potencial a própria rainha Dona Aldora, sua esposa raptada e que está pretensamente cativa no palácio de Gaia. É conjuntamente com ela que pretende traçar um plano para escapar da vigilância moura. Contudo, ao conseguir penetrar no palácio do rei mouro onde a rainha, sua esposa, estaria cativa, o rei Ramiro percebe que a rainha já preferia a esta altura viver com o rei Mouro.

Tendo sua presença traída e denunciada pela própria esposa, e sendo aprisionado pelo rei mouro, o monarca cristão percebe que mais do que nunca, terá de se valer de sua sabedoria. A única chave para a sua libertação e para o salvamento da sua vida será nesta narrativa o 'saber' - que neste caso tem múltiplos componentes: imaginação, capacidade de dissimulação, presença de espírito, calculo meticuloso de possibilidades, estratégia, frieza de análise, retórica, capacidade de argumentação ...

Simplificaremos a trama para atender aos limites do presente texto. Em uma intrincada manobra de argumentos e dissimulações, o rei Ramiro convence o rei mouro a executá-lo publicamente em um curral, mas depois de ser forçado a soprar sua corneta até perder as forças. Lembramos aqui que os guerreiros cristãos apenas aguardavam um sinal do rei - um toque prolongado de corneta - para se colocarem em ação. $\mathrm{O}$ curral que Ramiro induz o rei mouro a escolher para a execução é o local estrategicamente perfeito, tanto para o acesso dos guerreiros cristãos que estavam camuflados ali perto como para a ressonância do sinal sonoro que deverá convocá-los para o assalto.

$\mathrm{O}$ resto se passa tal como rei Ramiro previra. Conseguindo tanger seu corno em um espaço de grande ressonância, e tendo sucesso em fazer o rei Alboazer concentrar toda a população moura em uma praça fechada que logo se transformaria em um campo de massacre, tudo se resolve em uma batalha na qual os fidalgos cristãos têm a seu favor o elemento surpresa. No mais, verifica-se mais uma cena medieval de guerra no estilo da 'terra arrasada':

Com os guerreiros cristãos vencendo radical e definitivamente os inimigos mouros, o relato atinge seu equilíbrio final - à parte algumas pendências que devem ser resolvidas fora do plano de hostilidades entre cristãos e islâmicos. Uma destas pendências refere-se a rainha Dona Aldora. Já nas galés que levarão todos de volta à cristandade, o rei surpreende a rainha chorando, e pergunta-lhe porque está em prantos.:

\footnotetext{
" "Porque mataste aquele mouro, que era melhor que ti"”
} 
Eis a transgressão final. Não satisfeita em ter traído o marido durante o episódio de seu cativeiro, a rainha agora reitera a admiração pelo rei mouro Alboazer, afirmando ser ele melhor do que o rei Ramiro. Em uma Idade Média amplamente dominada pelos homens, e onde as mulheres pouco espaço haviam conquistado no âmbito das escolhas sobre seus destinos matrimoniais, isto é demais. Mesmo o príncipe Ordonho, filho de Ramiro e da rainha, que até ali se abstivera de emitir julgamento contra a mãe, não consegue conter sua indignação:

“ [Pai ...] 'Esto é o demo. Que querees dele, que pode seer que vos fugira?' E el rei mandou-a entom amarrar a ua moo e lança-la no mar. E des aquele tempo lhe chamarom Foz d'Ancora."

Depois de assassinar a esposa que ousara preferir como homem o inimigo mouro, Ramiro e seus guerreiros cristãos retornam à Espanha Cristã, onde o rei irá desposar - já devidamente batizada - a princesa moura cujo rapto havia iniciado tudo. E assim termina esta que é uma das mais longas narrativas do livro de linhagens.

A narrativa discutida - que de resto abriria espaço para serem repensadas inúmeras outras questões como a condição da mulher na Idade Meda Ibérica - é bem significativa para ilustrar a posição imaginária do Rei como "alma do reino", isto é, como algo que transcende o reino, que neste caso equivaleria ao corpo e que, no entanto o comanda. No tipo de relato examinado, bastante raro nas narrativas linhagísticas, o rei é capaz de agir independentemente do seu corpo de guerreiros, e ao mesmo tempo comandá-lo quando isto se faz necessário. Aqui temos a idéia da Alma que é independente do corpo, e que, no entanto, o governa e o dirige.

Ao mesmo tempo, este rei - isto se vê no decurso de todo o relato - possui mesmo uma licença para transgredir eventualmente as regras do ideário cavaleiresco - que constitui as normas que regem o corpo nobiliárquico - porque uma missão sagrada recebida de cima está pronta a redimir sempre os seus erros e conduzí-lo à vitória. Ao mesmo tempo, seus atributos mais decisivos referem-se muito mais ao campo da 'sabedoria' - ligado ao circuito imaginário da Alma - do que ao campo do 'heroísmo' que é ligado imaginariamente ao símbolo da cabeça ou ao âmbito da 'temperança', que é ligado imaginariamente ao símbolo do coração.

Com esta última posição - a do rei que se apresenta como Alma do reino, e não mais como Cabeça ou Coração - completa-se a tríade de imagens que encontrou expressão na célebre frase dos juristas de Afonso X, e que encontrou também o seu 
espaço nas narrativas linhagística da mesma época. Com o tempo, aproximando-se a modernidade que breve traria os grandes Estados fortemente centralizados em torno das monarquias absolutas, a metáfora da Cabeça tenderia a predominar cada vez mais como representação do poder em detrimento das metáforas do Coração e da Alma. A sobrevalorização da Cabeça, aliás, iria ser mais tarde aperfeiçoada com outra imagem do mesmo circuito imaginário - a do Rei-Sol - na qual a Cabeça adquire um sentido cósmico de um astro que paira soberanamente acima da sociedade que pretende governar. Mas aqui já estaremos lidando com um novo mundo, aonde o imaginário régio medieval vai cedendo espaço a novos imaginários do poder a caminho da Modernidade. 